\title{
直鎖アルキルベンゼンスルホン酸塩 $\left({ }^{14} \mathrm{C}-\mathrm{LAS}-\mathrm{Ca}\right.$, $\left.{ }^{14} \mathrm{C}-\mathrm{LAS}-\mathrm{Na}\right)$ の土壤及び植物中での挙動
}

\author{
川島和夫・竹野恒之 \\ 花王石䀶株式会社和歌山研究所（和歌山市湊 1334）
}

\author{
Fate of Linear Alkylbenzenesulfonates $\left({ }^{14} \mathrm{C}-\mathrm{LAS}-\mathrm{Ca},{ }^{14} \mathrm{C}-\mathrm{LAS}-\mathrm{Na}\right)$ \\ in Soils and Plant
}

\author{
Kazuo Kawashima and Tsuneyuki Takeno \\ Wakayama Research Laboratory, Kao Soap Co., Ltd (1334, Minato, Wakayama)
}

Fate of linear alkylbenzene $\left[{ }^{14} \mathrm{C}\right]$ sulfonates (LAS-Ca, LAS-Na) were investigated in two kinds of soil under upland condition in a biometric flask and ${ }^{14} \mathrm{C}-\mathrm{LAS}-\mathrm{Ca}$ showed as same fate as ${ }^{14} \mathrm{C}-\mathrm{LAS}-\mathrm{Na}$. Although there was a remarkable difference in the amount of unextractable residue between tested soils, the patterns of ${ }^{14} \mathrm{CO}_{2}$ evolution were similar, reaching $30 \sim 45 \%$ of the applied ${ }^{14} \mathrm{C}$ at $60 \mathrm{~d}$ after treatment. It was cleared that the benzene ring of LAS was inorganized in unsatured soils.

Nomovements of ${ }^{14} \mathrm{C}-\mathrm{LAS}-\mathrm{Ca}$ and ${ }^{14} \mathrm{C}-\mathrm{LAS}-\mathrm{Na}$ in peanuts were recognized even at $30 \mathrm{~d}$ after foliar application.

\section{1 緒 言}

直鎖アルキルベンゼンスルホン酸塩 (LAS) は多くの 分野で利用されている代表的な界面活性剂であり，特に 洗浄剤として多用されている。農薬工業においても界面 活性剂は製剂上，不可久な助剤で LAS も広く使用され ており，LAS のナトリウム塩 (LAS-Na) は水和剤のぬ れ剤等として, 分岐鎖アルキルベンゼンスルホン酸カル シウム塩 (ABS-Ca) 又は LAS のカルシウム塩 (LASCa) は乳化剂等として広く利用されている。日本に掠い てはいまだ, ABS-Caが取り扱いの容易さから農薬製剤 の助㨈として配合されているが, 難分解性の故に ABSCa の使用を全面的に禁止し, LAS-Ca だけを使用して いる国も見られる，この様な状況からわが国の市販農薬 製剤で LAS を含有した製品はいまだ多くはないが将来 増加するであろう。一方, LAS-Ca が落花生の 無 駄 花 の摘蕾剤として作用し増収効果をもたらすことを著者 ら゙は明らかにし，LAS-Ca について土壌及び植物中で の挙動を明らかにすることが重要となった。

LAS の安全性に関しては極めて多く研究されており 特に環境保護の観点から河川, 下水等での生分解性に関 する報告が多いが2),3，その多くは活性污泥によるLAS$\mathrm{Na}$ についての報告である。しかるに畑地条件（水不飽 和土壤）での生分解試験は特殊であり, そのような条件
下での LAS 生分解性に関する報告は見当たらず，植物 葉面での挙動に関する報告も著者らの調査した範囲では 認められない。

そこで著者らは 2 種類の土培についてベンゼン環に ${ }^{14} \mathrm{C}$ 標識した LAS-Ca 及び LAS-Na を用いてベンゼ ン環の無機化速度 $\left({ }^{14} \mathrm{CO}_{2}\right)$ を測定することによって畑 地条件下での LAS の生分解性及び塩の相違による举動 の変化について検討した。また, 落花生の葉面に散布さ れた ${ }^{14} \mathrm{C}-\mathrm{LAS}-\mathrm{Ca}$ 及び ${ }^{14}-\mathrm{LAS}-\mathrm{Na}$ の挙動についても 検討を加え，二，三の知見を得たので報告する。

\section{2 実験}

\section{$2 \cdot 1$ 標識化合物}

LAS-Ca, LAS-Na いずれもベンゼン環を ${ }^{14} \mathrm{C}$ でベ ルした標識化合物を用いた。 ${ }^{14} \mathrm{C}$-ベンゼンを 1 -ドデセ ンでアルキル化, 続いてスルホン化後, 水酸化カルシウ ムまたは水酸化ナトリウムで中和したものを購入した [米国 RCC 社製, 第一化学薬品 (株) 扱い:。

比放射能は ${ }^{14} \mathrm{C}-\mathrm{LAS}-\mathrm{Ca},{ }^{14} \mathrm{C}-\mathrm{LAS}-\mathrm{Na}$ 共に $3.5 \mathrm{mCi} /$ mmol で放射化学的純度は TLC (Merck, Silicagel 60 $\mathrm{F}_{254}$ 展開溶媒エ夕ノール: 水 $=9: 1 ）$ 検定で共に $99 \%$ であった。

\section{$2 \cdot 2$ 放射能の測定}

放射能はアルカリシンチレータ（トルエン $600 \mathrm{ml}$, メ 
Table-1 Properties of soil samples used.

\begin{tabular}{l|l|l|l|l|c|c|c}
\cline { 2 - 2 } Source & Clay mineral & Texture & $\begin{array}{c}\text { Clay content } \\
(\%)\end{array}$ & $\begin{array}{c}\mathrm{pH} \\
\left(\mathrm{H}_{2} \mathrm{O}\right)\end{array}$ & $\begin{array}{c}\text { Total-C } \\
(\%)\end{array}$ & $\begin{array}{c}\text { C.E.C. } \\
(\mathrm{m} . \mathrm{e} . / 100 \mathrm{~g})\end{array}$ & $\begin{array}{c}\text { Maximum water- } \\
\text { holding capacity } \\
(\%)\end{array}$ \\
\hline Wakayama & Kaolin & Silty loam & 21 & 6.7 & 1.7 & 11.8 & 52.3 \\
\hline Ohita & Allophane & Silty loam & 30 & 5.5 & 7.0 & 27.5 & 182.9 \\
\hline
\end{tabular}

チルセロソルブ $300 \mathrm{ml}$, エタノールアミン $100 \mathrm{ml}$, PPO $5 \mathrm{~g}$, POPOP $0.3 \mathrm{~g}$ ) またはジオキサン系シンチレ 一タ (Insta-Gel, Packard)を $10 \mathrm{ml}$ 加えて液体シンチ レーションカウンター(液シン. Aloka, LSC-651) で計 測し，外部標準線源法によりクエンチングの補正をし た。

土壤は風乾後,一部をひょう量し, 沪紙に包み込み自動 試料燃料装置 (Aloka, ASC-111) で然焼し, ${ }^{14} \mathrm{CO}_{2}$ とし て吸収剂(エタノールアミン:メタノール $=3: 2$ )に吸収 させトルエン系シンチレータ（トルエン $1 l, \mathrm{PPO} 10 \mathrm{~g}$, POPOP $0.5 \mathrm{~g}$ ) を混合後, 液シンで計測した。

植物は可溶化剤である Soluene 100 (Packard) を 1 $\mathrm{ml}$ 加え $50 \sim 60^{\circ} \mathrm{C}$ で一晚加温溶解後. 太陽光線下に 1 $\mathrm{d}$ 放置しクロロフィルを分解後, その一部にジオキサン 系シンチレータ $10 \mathrm{ml}$ を加え測定に供した。植物の才 ートラジオグラムはX線フィルム [富士フィルム (株)] を用いて室温にて $7 \mathrm{~d}$ 感光させた。

\section{$2 \cdot 3$ 土軖中での分解}

2 種類の土壤を供試し, その物性を Table-1 に示し た。装置は農薬の生分解を調べる慣行法で Fig.-1 に示 した。土㵝は生土のまま土塊を細かく砕き, 粒径 $5 \mathrm{~mm}$ 以上のれき(䃯)及び粗大有機物を選別除外後, 風乾させ た。風乾土 $50 \mathrm{~g}$ を $300 \mathrm{ml}$ 三角フラスコに入れ, 水分 は最大容水量の $60 \%$ に調整し, $30 \pm 1^{\circ} \mathrm{C}$ で 1 週間予備 培養後，投与した。すなわち ${ }^{14} \mathrm{C}-\mathrm{LAS}-\mathrm{Ca} 8.36 \mathrm{ppm}$ $(4.18 \mu \mathrm{Ci})$ 及び ${ }^{14} \mathrm{C}-\mathrm{LAS}-\mathrm{Na} 7.54 \mathrm{ppm}(3.77 \mu \mathrm{Ci})$ を エタノール: 水 $=1: 1$ 溶液の $30 \mu \mathrm{l}$ で希釈して風乾土 に添加し, 充分に混和させた後, $30 \pm 1^{\circ} \mathrm{C} に 2,7,12$, $60 \mathrm{~d}$ 培養した。培養後, $2 \mathrm{~N}$ 水酸化ナトリウムーメ夕,

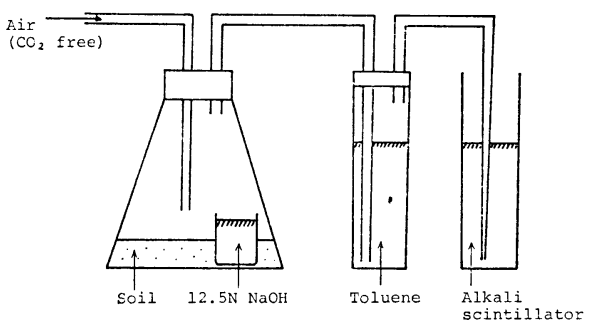

Fig.-1 Apparatus for the determination of liberated ${ }^{14} \mathrm{CO}_{2}$.
一ル水溶液 (16 g の水酸化ナトリウムを $15 \mathrm{ml}$ の水で溶 解させメタノールで $200 \mathrm{ml}$ に定容）を $5 \mathrm{ml}$ 添加してメ タノール $100 \mathrm{ml}$ で抽出し，遠心分離 $(3,000 \mathrm{rpm}, 10$ $\mathrm{min}$ ) 後, 上澄みを得た。再び土㙥を $50 \mathrm{ml}$ のメタノー ルで抽出, 続いて遠心分離で上澄みを得た。上澄みを減 圧濃縮し， $50 \mathrm{ml}$ に定容し，その一部を液シンに供し た。発生する ${ }^{14} \mathrm{CO}_{2}$ は $12 \mathrm{~N}$ 水酸化ナトリウム水溶液 及びェタノールアミン：メチルセロソルブ $=1: 3$ で捕 集し，60d の培養の際は $30 \mathrm{~d}$ 目に 2 種の捕集液を変え た。

\section{4 植物中での挙動}

落花生（品種：千葉半立）は 2 寸鉢で栽培され，主茎 葉数 $6 \sim 7$ 葉期のものを供試した。複葉の一枚にシリコ ーンリングをのせ，真空用グリースで固定させ，リング 内にエタノール: 水=1: 1 溶液で希釈した ${ }^{14} \mathrm{C}-\mathrm{LAS}-$ $\mathrm{Ca}$ また ${ }^{14} \mathrm{C}-\mathrm{LAS}-\mathrm{Na}$ をおのおの 1.39 , $\mathrm{Ci}$ また $1.26 \mu \mathrm{Ci}$ 滴下し. $30 \pm 1^{\circ} \mathrm{C}$ にて $7,30 \mathrm{~d}$ 栽培した。

\section{3 結果及び考察}

\section{1 土㙴中での LAS の挙動}

和歌山及び大分土壤中での LAS-Ca の挙動について 調ベた結果を Table-2, LAS-Na についての結果を Table-3 に示した。LAS-Ca のメタノール可溶量は経 日的に減少し， 2 種類の土壤共に添加後 $60 \mathrm{~d}$ 目では全 放射能の約 $5 \%$ まで低下した。メタノール可溶量の減少 程度は 2 種類の土壤で異なり. 大分土潩の方が速く, LAS-Ca の経日的変化は LAS-Na とほぼ同じパターン を示した。土壌吸着量の経日的変化についても LAS-Ca と LAS-Na はほぼ同じ傾向が認められたが，土壌によ りかなりパターンが異なり, 和歌山土壌では吸着量がわ ずかではあるが増大する傾向が認められた。しかるに大 分土壌では $7 \mathrm{~d}$ 目で最大の吸着量を示し, その後, 徐々 に減少した。トルエンに溶解する揮発性有機物は LAS$\mathrm{Ca}$ 及び LAS-Na 共に 2 種類の土壌で全く検出されな かった。しかし, Steber $\left.{ }^{4}\right)$ はミニチュア活性污泥装置を 用いて流出する水溶液中に揮発性酸（例えば酢酸）の存 在を報告しており, ${ }^{14} \mathrm{CO}_{2}$ 捕集用のアルカリ水溶液に揮 発性酸が吸収された可能性もある。 ${ }^{14} \mathrm{CO}_{2}$ 発生量は投与 後，わずか $2 \mathrm{~d}$ 目で検出され， $60 \mathrm{~d}$ 目では和歌山土壤 で全放射能の 40 45\%, 大分土壌で 30〜 40\% が検出 され, 水不飽和土壌 (畑地条件) においても LAS のべ 
Table-2 Distribution of ${ }^{14} \mathrm{C}$ in soils after application of ${ }^{14} \mathrm{C}-\mathrm{LAS}-\mathrm{Ca}$.

\begin{tabular}{|c|c|c|c|c|c|c|c|c|}
\hline \multirow{3}{*}{ Fraction } & \multicolumn{8}{|c|}{$\%$ of the applied ${ }^{14} \mathrm{C}$} \\
\hline & \multicolumn{4}{|c|}{ Wakayama soil } & \multicolumn{4}{|c|}{ Ohita soil } \\
\hline & $2 \mathrm{~d}$ & $7 \mathrm{~d}$ & $12 \mathrm{~d}$ & $60 \mathrm{~d}$ & $2 \mathrm{~d}$ & $7 \mathrm{~d}$ & $12 \mathrm{~d}$ & $60 \mathrm{~d}$ \\
\hline $\mathrm{CO}_{2}$ & 0.10 & 2.57 & 22.99 & 39.24 & 0.04 & 0.29 & 12.74 & 31.00 \\
\hline Volatile materials & ND & ND & ND & ND & ND & ND & ND & ND \\
\hline Methanol extracts & 86.30 & 69.81 & 29.28 & 4.51 & 69.24 & 22.90 & 17.45 & 6.85 \\
\hline Soil residue & 7.19 & 16.77 & 28.78 & 31.71 & 30.26 & 53.26 & 46.78 & 30.82 \\
\hline Total recovery & 93.59 & 89.15 & 81.05 & 75.46 & 99.54 & 76.45 & 76.97 & 68.67 \\
\hline
\end{tabular}

ND : not detected

Table-3 Distribution of ${ }^{14} \mathrm{C}$ in soils after application of ${ }^{14} \mathrm{C}-\mathrm{LAS}-\mathrm{Na}$.

\begin{tabular}{|c|c|c|c|c|c|c|c|c|}
\hline \multirow{3}{*}{ Fraction } & \multicolumn{8}{|c|}{$\%$ of the applied ${ }^{14} \mathrm{C}$} \\
\hline & \multicolumn{4}{|c|}{ Wakayama soil } & \multicolumn{4}{|c|}{ Ohita soil } \\
\hline & $2 \mathrm{~d}$ & $7 \mathrm{~d}$ & $12 \mathrm{~d}$ & $60 \mathrm{~d}$ & $2 \mathrm{~d}$ & $7 \mathrm{~d}$ & $12 \mathrm{~d}$ & $60 \mathrm{~d}$ \\
\hline $\mathrm{CO}_{2}$ & 0.06 & 1.36 & 23.16 & 46.90 & 0.06 & 0.21 & 18.53 & 40.96 \\
\hline Volatile materials & ND & ND & ND & ND & ND & ND & ND & ND \\
\hline Methanol extracts & 77.15 & 74.05 & 23.51 & 4.77 & 62.70 & 18.29 & 13.27 & 6.51 \\
\hline Soil residue & 9.47 & 19.59 & 34.34 & 39.96 & 37.24 & 76.40 & 42.32 & 39.43 \\
\hline Total recovery & 86.68 & 95.00 & 81.01 & 91.63 & 100.00 & 94.90 & 74.12 & 86.90 \\
\hline
\end{tabular}

ND : not detected

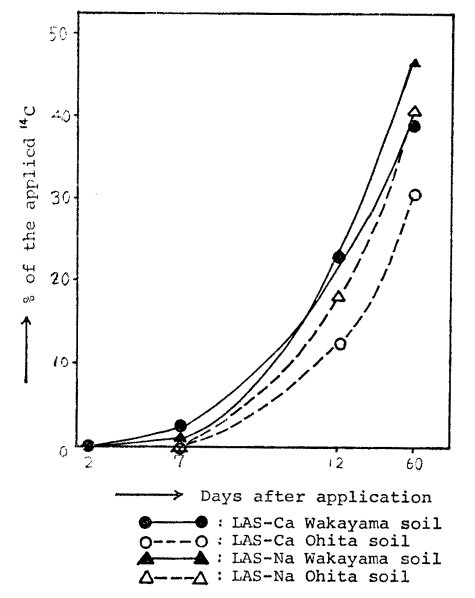

Fig.-2 Evolution of ${ }^{14} \mathrm{CO}_{2}$ from soils treated with ${ }^{14} \mathrm{C}$-LAS-Ca $(8.36 \mathrm{ppm})$ or ${ }^{14} \mathrm{C}$ LAS-Na (7.54 ppm) under upland condition.

ンゼン環まで無機化されることが明らかとなった。 LAS-Ca は水に難溶であり, 一方, LAS-Na は水に可 溶であり, その物性の相違により, 当初 LAS-Ca と LAS-Na では生分解速度が異なり，最終的にベンゼン 環の無機化速度にかなり差が見られるのではないかと 考えられたが，Fig.-2 に LAS-Ca 及び LAS-Na の ${ }^{14} \mathrm{CO}_{2}$ 発生量を示すように極めて類似したパターンが得
られ，LAS の塩の相違は水不飽和土塞による代謝に影 響を及ぼさないことが明らかとなった。

吉野 ${ }^{5}$ は水飽和土壤（湛水土壤, 水田条件）における LAS-Na の挙動を研究し, 3 種類の土埣について LAS の固定力（吸着力）を調べ腐植質または粘土質の土畩は 固定力が高く砂質土壊は固定力が低いと報告しており， 土壌カラムを用いて Klein $5^{6)}$ \& ABS-Na が有機物含 量の高い土壌ほど吸着が強い結果を報告している。ま た，代表的な殺虫剤である $\mathrm{MEP}[O, O$-dimethyl-O(3-methyl-4-nitrophenyl) phosphorothioate] の土壊中 の吸着について土壌中の有機物含量と相関のあることが 報告されており ${ }^{7)}$ ，本報の結果と一致している。本報の 大分土壌では土壤吸着量が $7 \mathrm{~d}$ 目に最大に達し徐々に減 少しているが，大分土壌より有機物含量の少ない和歌山 土壤ではさらに培養期間を延長することにより吸着量が 減少するものと考えられる。メタノール可溶量について は強アルカリを添加して抽出していることより, 弱く土 壌に結合したもの，それにかなり強く結合したものも一 部抽出されており, その大半は LAS そのもの及び短鎖 LAS と推測される ${ }^{8)}$ 。土畩吸着量は微生物に取り込ま れた生物的な量及び土壤中の腐植酸, フルボ酸等に同化 された化学的な量の総和として現れているものと考察さ れる。

Robeck ら ${ }^{9}$ は土壤カラムを用いた実験手法により水 不飽和土壌中で ABS-Na を含む有機化合物がまず吸着 
し生分解されることを報告しており，窪寺ら ${ }^{10)}$ も活性污 泥による LAS-Na の生分解過程には吸着, 順化, 分解 の 3 期間のあることを示唆している。LAS-Na のベン ゼン環の生分解に関しては Gledhill ${ }^{11)}$ が振とうフラス 二培養法で $30 \mathrm{~d}$ 後に ${ }^{14} \mathrm{CO}_{2}$ 発生率が 全放射能の $60 \%$ に達すると報告し, Steber ら“滵閉フラスコ法で表面 水における LAS-Na のベンゼン環の無機化が 40〜 60d 後に $72 \%$ に達することを報告している。また， Hud= dleston ら ${ }^{12}$ 戊半連続式活性污泥法を 用いてベンゼン環 の開裂は $95 \%$ 起こり，そのうち ${ }^{14} \mathrm{CO}_{2}$ 生成率が $62 \%$ であると報告している。一方，中村ら ${ }^{13)}$ は代表的な除草 剂でベンゼン環に ${ }^{14} \mathrm{C}$ を有するべンチオカーブ $[S-(4-$ chlorobenzyl)-N, $N$-diethyl thiocarbamate ]を用い，畑 地, 酸化的たん(湛)水及び還元的たん水条件下で分解を 調べ, 酸化的(好気的)条件でベンチオカーブが速やかに 分解し, 畑地条件が最も顕著に ${ }^{14} \mathrm{CO}_{2}$ を生成することを 報告している。本報では水不飽和土㙵による LAS-Ca 及び LAS-Na のベンゼン環の無機化を調ベ，活性污泥 による無機化速度よりは遅く, 添加後 $60 \mathrm{~d}$ 目で 30 45 $\%$ の ${ }^{14} \mathrm{CO}_{2}$ 生成を認め沉が，たん水条件下ではさらに無 機化が遅くなるものと考えられる。水不飽和土壤による LAS の生分解過程にも吸着, 順化, 分解の 3 期間があ ると考えられるが，大分土㙵と和歌山土壤では土壤吸着 量のパターンが著しく異なり, 有機物含量の高い大分土 袞の方がはるかに強い吸着力を示したにもかかわらず， ${ }^{14} \mathrm{CO}_{2}$ 発生量はほとんど同じか，逆に和歌山土䇎の方が わずかではあるが高い ${ }^{14} \mathrm{CO}_{2}$ 発生量を示したこと及び 添加後 $60 \mathrm{~d}$ 目でも土壤吸着量がかなり高いことより，
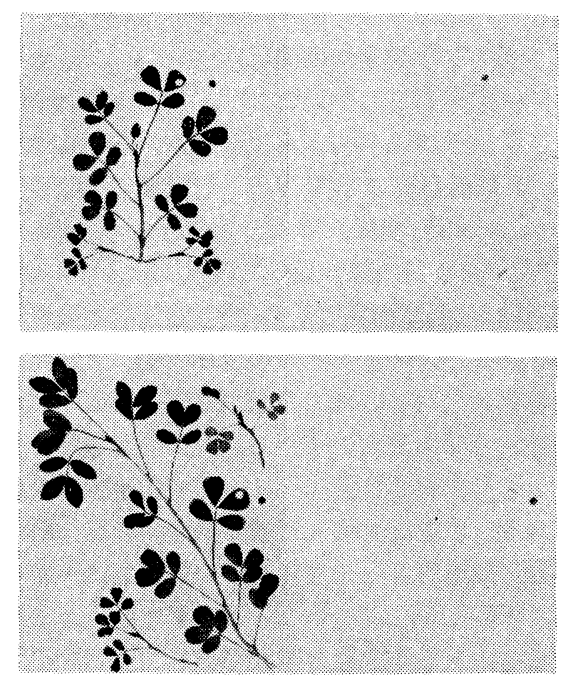

$7 \mathrm{~d}$

$30 \mathrm{~d}$

Fig.-3 Autoradiograms (right) and photographs (left) of peanuts harvested at $7 \mathrm{~d}$ and $30 \mathrm{~d}$ after foliar treatment with ${ }^{14} \mathrm{C}-\mathrm{LAS}-$ Ca.
E. Table-4 Distribution of ${ }^{14} \mathrm{C}$ in peanuts at $7 \mathrm{~d}$ and $30 \mathrm{~d}$ after foliar application with ${ }^{14} \mathrm{C}$-LAS$\mathrm{Ca}$ or ${ }^{14} \mathrm{C}-\mathrm{LAS}-\mathrm{Na}$.

\begin{tabular}{c|c|c|c|c|c|}
\hline \multirow{2}{*}{ Section } & \multicolumn{3}{|c}{$\%$ of the applied ${ }^{14} \mathrm{C}$} \\
\cline { 2 - 6 } & LAS-Ca & LAS-Na \\
\cline { 2 - 6 } & $7 \mathrm{~d}$ & $30 \mathrm{~d}$ & $7 \mathrm{~d}$ & $30 \mathrm{~d}$ \\
\hline $\mathrm{a}$ & 78.52 & 80.54 & 79.76 & 70.10 \\
$\mathrm{~b}$ & $\mathrm{ND}$ & 0.12 & $\mathrm{ND}$ & $\mathrm{ND}$ \\
$\mathrm{c}$ & $\mathrm{ND}$ & $\mathrm{ND}$ & $\mathrm{ND}$ & $\mathrm{ND}$ \\
$\mathrm{d}$ & $\mathrm{ND}$ & $\mathrm{ND}$ & $\mathrm{ND}$ & $\mathrm{ND}$ \\
$\mathrm{e}$ & $\mathrm{ND}$ & $\mathrm{ND}$ & $\mathrm{ND}$ & $\mathrm{ND}$ \\
\hline Total & 78.52 & 80.66 & 79.76 & 70.10 \\
\hline
\end{tabular}

活性污泥の場合とは若干異なり, LAS 分解物のベンゼ ン環が完全に無機化され二酸化炭素になる前に再度, 土 壤に同化または微生物に取り込まれる量が多いのではな いかと推定される。

\section{2 植物体での LAS の挙動}

落花生の葉面での LAS-Ca 及び LAS-Na の挙動を 調ベたが，そのオートラジオグラムを Fig.-3 に示し た。処理した部位にのみ放射能が認められ，処理後 $30 \mathrm{~d}$ 目でも全く移行していないことが明らかとなった。葉身 と葉柄からの抽出物は定量的にこのことを裹付けている (Table-4)。しふし，LAS-Ca の $30 \mathrm{~d}$ 目で投与した葉 身の対生葉にわずかではあるが放射能が認められたが, 豆科植物に特有な葉の開閉運動による接触に起因するも のと考えられる。回収率が 70 80\% であるのは投与量 の 20 30\%がシリコーンリングに付着したためである。

Smith ら ${ }^{14}$ ) は非イオン性界面活性剂である ${ }^{14} \mathrm{C}-\mathrm{Tween}$ 20 (ポリオキシェチレンソルビタンモノラウラート)に ついていんげんの葉及び根からの取り込みは極めて少な いことを報告しており，Klein ら ${ }^{6}$ は ${ }^{35} \mathrm{~S}-\mathrm{ABS}-\mathrm{Na}$ を用 いて水耕截培でひまわりと大麦の根からの移行について 調べ，大半が根にあり，茎，葉への移行の少ないことを 報告している。一方, 吉野 ${ }^{5}$ は ${ }^{35} \mathrm{~S}-\mathrm{LAS}-\mathrm{Na}$ を用いて水 耕栽培による根からの移行について調べ, 水稲, 小麦, きゅうりの葉, 茎, 根等に一様に取り込まれることを報 告している。本報の結果も踏まえて考えると界面活性剤 の植物体一の取り込みは予期に反して容易ではなく, 特 に葉面からの吸収, 移行は難しいものと推測される。

終わりにのぞみ, 本研究の発表を許可された花王石粗株式会 社㳊感謝します。

（昭和 57 年 3 月 15 日受理）

\section{文献}

1）鈴木 寿, 乙部逸夫, 前田清一, 竹野恒之, 日作紀, 第 164 回講演要旨集 (1977) p. 111

2) R.D. Swisher, Tenside Deterg., 18, 57 (1981)

3) E.A. Setzkorn, R.L. Huddleston, J. Am. Oil Chem. 
Soc., 42, 1081 (1965)

4) J. Steber, Tenside Deterg., 16, 140 (1979)

5) 吉野 実, 農業技術, 29，63 (1974)

6) S.A. Klein, D. Jenkins, P.H. McGauhey, J. Water Poll. Control, 35, 636 (1963)

7) K. Nambu, H. Ohkawa, J. Miyamoto, J. Pesticide Sci., 5, 177 (1980)

8) P. Schöberl, E. Kunkel, Tenside Deterg., 14, 293 (1977)

9) G.G. Robeck, J.M. Cohen, W.T. Sayers, R.L.
Woodward, J. Water Poll. Cont. Fed., 35, 1225 (1963)

10）窪寺忠良, 武藤利雄, 山本龍夫, 油化学, 27, 838 (1978)

11) W.E. Gledhill, Appl. Microbiol., 30, 922 (1975)

12) R.L. Huddleston, A.M. Nielsen, Soap/Cosmetic/ Chemical Specialties, 34 (1979)

13) Y. Nakamura, K. Ishikawa, S. Kuwatsuka, $J$. Pesticide Sci., 2, 7 (1977)

14) L.W. Smith, C.L. Foy, J. Agri. and Food Ches mistry, 14, 117 (1966) 